\title{
Exploration and Practice of International IT Project Education
}

\author{
Dan $Y U^{*}$, Jing SUN and Ming-hao NING \\ Dalian Neusoft university of Information, Liaoning Province Dalian City, China \\ ${ }^{*}$ Corresponding author
}

Keywords: OBE, Internationalization IT project education, Innovation, Entrepreneurship.

\begin{abstract}
With the globalization of education's development, the internationalization program education plays an important role in engineering education. This paper mainly focuses on innovative exploration and practice of international IT project education from the perspective of innovation and entrepreneurship education. Based on the OBE theory, this paper explored and analyzed education mode, teaching methods and the corresponding results of internationalization IT project education. This paper also took the internationalization project education in Dalian Neusoft university of Information(DNUI) as an example. The practice framework, implementation priorities, problems or the project had been discussed in this paper. The research will also provide references for the engineering education model and innovation ways based on OBE Theory.
\end{abstract}

\section{Introduction}

With the deepening development of CDIO engineering educational theory, Outcomes-Base Education (OBE) mode is frequently used as the guidance to implementation of CDIO engineering education [1]. As the core carrier of CDIO theory, project education plays a crucial part in engineering education, more educators start to explore the application of OBE mode in project education field [2].

Since 2015, Chinese universities started to deepen education reformation by innovation and entrepreneurship education. Various universities explore the development pattern and method of innovation and entrepreneurship education. However, applying OBE theory to the research and practice of innovation and entrepreneurship education is relatively rare.

According OBE theory, the outcome of IT project education is technical application, with assessment on technology adaptability and correctness in general. The outcome of innovation and entrepreneurship education maybe be an idea, a demo or a business plan, with assessment on the business value and feasibility. If putting innovation and entrepreneurship education elements into IT project education, that will add IT project value and social culture value, reach the standard CDIO for education of all systems thinking, business skills and teamwork ability. By literatures review, this paper finds that there is seldom research which focused on putting innovation and entrepreneurship education elements into IT project education. Therefore, this paper would explore IT project education by putting innovation and entrepreneurship education elements according OBE theory.

\section{OBE}

The concept OBE, or Intended Learning Outcomes (ILE), is originated from the basic education reform in the US and Australia. Now it is very popular in engineering education. Since 1994 OBE method was implemented in American education field, a serious of educational systems across the world have carried out experiments in different aspects and levels.

OBE theory is the derivation and development of Taylor's, Bloom's learning theory and Competency Based Education. OBE theory emphasizes that educators must have a clear vision of students' ability and level so that to design suitable educational structures and courses ensuring that students must achieve these educational goals. OBE theory focus on student's acquirement to ensure that the learners may acquire the knowledge, ability and mortality for society. OBE theory emphasizes the flexibility of education. On the basis of a clear output target, OBE theory is not 
confined to specific guidance. Educators may conduct a various of teaching and evaluation methods according to the types of learners.

The OBE education model mainly includes four steps: learning output definition, learning output realization, learning output evaluation and learning output implementation. The model is consistent with the PDCA theory (plan, do, check, action) in the management field [3].

\section{International IT Project Education}

The essence of project is a task. Project education can be named as task education or practice education. Teachers and students acquire relevant knowledge by participating in related projects or tasks together. The aim of project education, which similar to case teaching methodology, is to dynamically combine theory and practice to cultivate student's comprehensive and creative problem-solving abilities. A project can be defined as a course, it is often called project practice or training projects, for instance, CDIO comprehensive milestone course or project require students to complete an integrated project with multi-course knowledge [4].

The IT project in this paper refers to the curriculum-equivalent technical application project, with assessment on student's technology adaptability and correctness, in short as IT project. This type project is crucial for students whose majors are information technology related.

The mode of international cooperation in universities is the main form of international education interaction and the most effective way of interaction. At present, the scope of international exchange and cooperation between domestic and foreign universities involves almost all fields, but the core content of internationalization is focused on co-education field. International IT project refers to integrating internationalized elements into the design and implementation of IT projects. It is a kind of international cooperation in universities and is usually an international exchange course. The internationalization of a project is not only reflected on students and teachers from different countries, but also reflected on the tasks which student need to finished.

\section{Innovation and Entrepreneurship Education}

Entrepreneurship education had been changed to "innovation and entrepreneurship education" by China's Ministry of Education in 2010. It marked the inclusion of innovation education into the start-up education formally. The importance and fundamental role of innovation in entrepreneurship were clarified. It highlighted the integration of innovation and entrepreneurship education. "Innovation and entrepreneurship education" includes "innovation education" and "entrepreneurship education", but not both are simple equivalents. "Innovation and entrepreneurship education" is a comprehensive, continuous and integrated education of innovation and entrepreneurship [5].

Innovation and Entrepreneurship Mode. Innovation is the starting point of entrepreneurial process and a guarantee of successful entrepreneurship. According to different types of innovation, entrepreneurship can be divided into three modes. The first model is based on the invention and it is referred to invention-based innovation and entrepreneurship. The foundation of this model is the invention and its core are the original science and technology. The second model is application-based innovation and entrepreneurship. Such entrepreneurship refers to the use of existing technologies to optimize or improve a product or service. The third model is based on business model innovation which stimulates entrepreneurship. This type of entrepreneurship is based on the innovation of business rules. Entrepreneurs reinvent the business process or adopt a new way to run the business, thereby increasing the value of the business [6].

Innovation and Entrepreneurship Education Mode (IEEM). Innovation and entrepreneurship education can be divided into three types corresponding to the above three innovation and entrepreneurship models, which are, invention-based innovation and entrepreneurship education, application-based innovation and entrepreneurship education, business model innovation and entrepreneurship education. Due to the key points of success in the three-differed innovation and entrepreneurship models are different, the differences between these three kinds of education are reflected in the emphasis of education and the applicable population. Invention-based innovation and entrepreneurship education is more suitable for talent cultivation in research field. Improved 
innovation and entrepreneurship is more suitable for talent cultivation in the field of application. Business model innovation and entrepreneurship is more suitable for talent cultivation in business related fields, as shown in Table 1.

Table 1. Key point of success and focus of entrepreneurship education in three kinds of IEEM

\begin{tabular}{|c|c|c|c|}
\hline IE Model & Key Points of Success & Focus of IE Education & Educational Object \\
\hline Invention Type & $\begin{array}{c}\text { The Advancement of } \\
\text { Inventive Technology }\end{array}$ & $\begin{array}{c}\text { Scientific Research } \\
\text { Transformation Ability }\end{array}$ & Talents in Research Field \\
\hline Improved Type & $\begin{array}{c}\text { The Value of Application } \\
\text { Add }\end{array}$ & $\begin{array}{c}\text { Customer Needs Identification } \\
\text { Value Transmission }\end{array}$ & $\begin{array}{c}\text { Talents in the Field of } \\
\text { Application }\end{array}$ \\
\hline $\begin{array}{c}\text { Business Model } \\
\text { Innovation Type }\end{array}$ & $\begin{array}{c}\text { Commercial Operation } \\
\text { Ability }\end{array}$ & $\begin{array}{c}\text { Comprehensive Quality of } \\
\text { Entrepreneurs }\end{array}$ & $\begin{array}{c}\text { Talents in the Field of } \\
\text { Business }\end{array}$ \\
\hline
\end{tabular}

From Innovation to entrepreneurship needs to go through three stages, namely, idea, innovation and entrepreneurship. The first stage is the idea about a product or service. The second stage is the innovation realization, namely the design and implementation of product or service. The third stage is the implementation of entrepreneurship. The common forms of innovation and entrepreneurship education in high level education include curriculums, project practice and business incubation. This research focuses on the innovation and entrepreneurship projects that "make idea become reality". Based on the OBE mode, the results of innovation and entrepreneurship projects are "three new things" which corresponds with three stages of innovation and entrepreneurship, new ideas, new products and new businesses.

\section{International Innovation and Entrepreneurship IT Project}

Base on the above, the international innovation and entrepreneurship IT project (IIEITP) is an integrated IT project with international, innovation and entrepreneurship elements. The design and implement of IIEITP not only aims to achieve the educational goal of innovation and entrepreneurship, but also get the educational goal of international IT project. Therefor the IIEITP should not only concentrate on developing students' international vision, consciousness but also should focus on students' ability of innovation and entrepreneurship, IT ability and industry knowledge.

To achieve this goal, this paper designs the project elements mode model of IIEITP in figure 1. IIEITP should include three fields task, which includes international task, innovation and entrepreneurship tasks, and IT tasks at least, those are shown in the following figure 1. In the chart, internationalized elements include team participants from multiple countries, demands of project derive from different countries, or users of the project distribute globally. The elements of innovation and entrepreneurship include idea generation, innovative product formation, product transformation into entrepreneurship, etc. IT project elements include the use of IT related tools and platforms, analysis of related industries and analysis of the technical use effect.

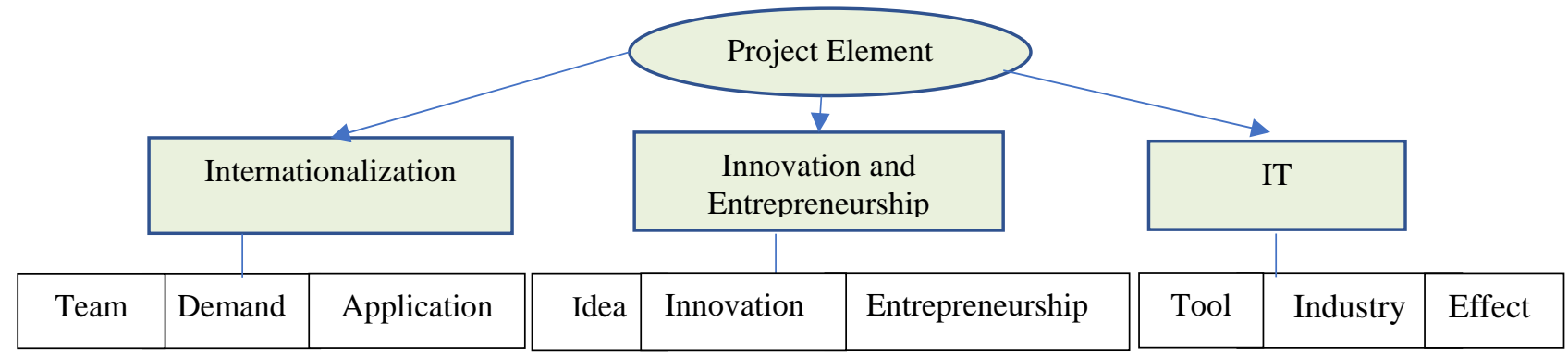

Figure 1. Project elements mode

Based on OBE mode of education, the design of IIEITP should include four stages, defining learning, realizing and using learning output, as shown in table 2. These learning output designs should include three fields elements, which are internationalization, innovation and entrepreneurship, and IT elements. 
Table 2. Design of internationalized IT innovation and entrepreneurship project based on OBE

\begin{tabular}{|c|c|c|c|}
\hline $\begin{array}{c}\text { Learning } \\
\text { Output }\end{array}$ & Internationalization field & $\begin{array}{c}\text { Innovation Entrepreneurship } \\
\text { field }\end{array}$ & IT field \\
\hline Defining & $\begin{array}{c}\text { Internationalization of } \\
\text { Demand and Product } \\
\text { Application }\end{array}$ & $\begin{array}{c}\text { Creative Proposal, Product } \\
\text { Prototype, Entrepreneurial } \\
\text { Plan }\end{array}$ & Use IT to Complete the Product \\
\hline Realizing & $\begin{array}{c}\text { Transnational Group } \\
\text { Learning }\end{array}$ & Task Design & $\begin{array}{c}\text { Use IT to Realize Product } \\
\text { Prototyp }\end{array}$ \\
\hline $\begin{array}{c}\text { Evaluatin } \\
\text { g }\end{array}$ & $\begin{array}{c}\text { Team Evaluation; Product } \\
\text { Application Object } \\
\text { Evaluation }\end{array}$ & $\begin{array}{c}\text { Rationality Evaluation; Value } \\
\text { Evaluation }\end{array}$ & $\begin{array}{c}\text { Technical Rationality } \\
\text { Evaluation; Technical Effect } \\
\text { Evaluation }\end{array}$ \\
\hline Using & Product Promotion & Investment Attraction & Product Application \\
\hline
\end{tabular}

\section{Case of IT Innovation And Entrepreneurship Project}

Project Background. This project can alternative credits which is an inter-school cooperation project in Dalian Neusoft University of Information and the university of Queensland. The students coming to China are sponsored by the Australian government to participate in a four-week innovation and entrepreneurship of IT project. Eligible students will receive the corresponding credits.

Project Participants and Groups. In order to reflect internationalized and project-oriented instructional design, Students participating in the project include not only 20 undergraduates from the School of Information Technology and Engineering in UQ, but also 15 undergraduates from the department of Computer Science and Technology and Software Engineering in DNUI. They were mixed up into six project teams. Project's instructors consist of two parts, including two teachers of the college of information technology and engineering from UQ, and several excellent teachers in the college of international education, the department of innovation and entrepreneurship, computer science and technology and software engineering in DUNI.

OBE-based Project Design. This Project develops skills in relation to industrial experiences in software development in a company setting. Students study in DNUI and visit NeuSoft Company, (the largest IT solutions and services provider company in China with a global presence). Skills in entrepreneurship, business communications, project development, team building, software development, are developed as an IT industrial program. This course involves some language training (Chinese), condensed team work and IT company visits.

This project will provide students with training and practical experience on how to initiate an innovative IT product, showing them what is required to get it market ready and succeed in the global marketplace. The training and practicum will be 4 weeks in duration and is based on course material and a practicum offered at DNUI. The project builds upon the strong existing links between DNUI and NeuSoft. The training will be provided through DNUI's School of Innovation \& Entrepreneurship where students will receive expert advice on presenting business cases, negotiating with angel investors and conducting market investigations. As part of the practicum, the students will work in groups under the guidance and mentorship of IT professionals and entrepreneurs to create a new IT product and establish a pseudo-company to develop and market this product.

The OBE education model consists of four steps, namely defining, achieving, evaluating, and using learning output. The learning outputs in this project include four deliverables, namely creative proposals, user portraits, product prototypes and business plans. The corresponding evaluation includes four aspects, namely market expectation, technical feasibility, commercial feasibility and commercial durability. The specific design is shown in Table 3. 
Table 3. Elements achievement and evaluation design of international innovation and entrepreneurship IT project

\begin{tabular}{|c|c|c|c|c|}
\hline Number & Element & Constitution & Achievement & Evaluation \\
\hline \multirow{2}{*}{1} & Globalization & Participants & Business Plan & Business Persistence \\
\cline { 3 - 5 } & & Project Source & Customer Analysis & Market Expectation \\
\cline { 3 - 5 } & & User & Customer Analysis & Market Expectation \\
\hline \multirow{2}{*}{2} & Innovation and \\
& \multirow{2}{*}{ Entrepreneurship } & Creativity & Creative Ideas & Market Expectation \\
\cline { 3 - 5 } & & User Portrait & Market Expectation \\
\cline { 3 - 5 } & & Innovation & Product Prototype & Technical Feasibility \\
\cline { 3 - 5 } & & Entrepreneurship & Business Model Canvas & Commercial Viability \\
\cline { 3 - 5 } & & & Plan New Business & Business Persistence \\
\hline \multirow{2}{*}{3} & \multirow{2}{*}{ IT } & IT Tool & Prototype & Technical Feasibility \\
\cline { 3 - 5 } & & IT platform In Industry & Technical Analysis & Technical Feasibility \\
\hline
\end{tabular}

Project Components and Assessments. The project is based on the following components and assessments (100\%): Team building and Project Report (30\%), Prototype Demo (30\%), Entrepreneurship Training (40\%).

Project Feedback and Improvement Design. In order to understand the implementation effect of the project, a feedback and evaluation mechanism was constructed involving the participation of teachers, students and managers from Australia and Chinese, the specific contents are shown in the table 4 below.

Table 4. Project feedback and improvement design

\begin{tabular}{|l|l|l|l|}
\hline \multicolumn{1}{|c|}{ Link } & Feedback Way & \multicolumn{1}{c|}{ Feedback Content } & \multicolumn{1}{c|}{ Improvement Measures } \\
\hline $\begin{array}{l}\text { Teachers' } \\
\text { Evaluation } \\
\text { of UQ }\end{array}$ & $\begin{array}{l}\text { Discussion, } \\
\text { Questionnaire }\end{array}$ & $\begin{array}{l}\text { Student Experience, Student } \\
\text { Learning Status, Learning } \\
\text { Effectiveness }\end{array}$ & $\begin{array}{l}\text { Teaching Methods, Joint Design } \\
\text { Courses, Deep Joint Teaching }\end{array}$ \\
\hline $\begin{array}{l}\text { Management } \\
\text { Feedback of }\end{array}$ & $\begin{array}{l}\text { Depth } \\
\text { Interviews }\end{array}$ & $\begin{array}{l}\text { Students Learning Experience, } \\
\text { Learning Content, Teaching } \\
\text { Methods }\end{array}$ & Shared Information \\
\hline $\begin{array}{l}\text { Students' } \\
\text { Evaluation } \\
\text { of UQ }\end{array}$ & $\begin{array}{l}\text { Questionnaire, } \\
\text { Discussion }\end{array}$ & $\begin{array}{l}\text { Learning Experience and } \\
\text { Content, Teaching and } \\
\text { Evaluation Methods }\end{array}$ & $\begin{array}{l}\text { Teaching Content, Teaching } \\
\text { Rhythm, Student Approach }\end{array}$ \\
\hline $\begin{array}{l}\text { Students' } \\
\text { Evaluation }\end{array}$ & $\begin{array}{l}\text { Questionnaire, } \\
\text { Discussion }\end{array}$ & $\begin{array}{l}\text { Learning Experience and } \\
\text { Content, Teaching and } \\
\text { Evaluation Methods }\end{array}$ & $\begin{array}{l}\text { Strengthen Language Preparation, } \\
\text { International Etiquette Training, } \\
\text { etc. }\end{array}$ \\
\hline $\begin{array}{l}\text { Teachers' } \\
\text { Evaluation }\end{array}$ & $\begin{array}{l}\text { Brainstorm, } \\
\text { Self-report. }\end{array}$ & $\begin{array}{l}\text { Learning Experience and } \\
\text { Content, Curriculum Design }\end{array}$ & $\begin{array}{l}\text { Improvement of Teaching } \\
\text { Management, Improvement of } \\
\text { Students' Evaluation }\end{array}$ \\
\hline
\end{tabular}

\section{Research Implication}

Overall, this paper is an exploration and application of OBE theory in the field of innovation and entrepreneurship education and IT education. It is a deliberate attempt to integrate innovation and entrepreneurship education with professional education practice. Although the educational object of the project is a student who has IT background, the design model and teaching design of the project can be applied to other professional projects combined with innovation and entrepreneurship education.

\section{Acknowledgement}

This work is support by Research project of undergraduate teaching reform of Liaoning Province in 2016, named "Research and Practice on the construction of the universal innovation and entrepreneurship curriculum system in Universities”. 


\section{References}

[1] P H Gu, Hu W L, et al. OBE Engineering Education based on the model in Shantou university Research in Higher Education of Engineering. (2014) 01,27-37.

[2] D F Zheng, C Li, The research on OBE engineering education philosophy and practice teaching system of chemical major. Experimental Technology and Management, 34 (2017) (05), 154-160.

[3] Chandrama A Outcome-Based Education (OBE): A New Paradigm for Learning, (2003) 7(3).

[4] HAN D D, Research on CDIO based software engineering practice teaching Science-Technology and Management (2014) 16(2), 66-69.

[5] B A San, L Cai, XF Lu, L Zhao. The definition, dimensions and measurement of entrepreneurial learning Studies in Science of Science (2014)32 (12),1867-1875.

[6] Z R Wang, The General Theory of University-Wide Innovation and Entrepreneurship Education Ideological and Political Education Research (2016) 32 (04),130-134. 